\title{
Rancang Bangun Sistem Pintu Antisipasi Covid-19 Dengan Sanitizer Otomatis Menggunakan Sensor Ultrasonik Arduino
}

\author{
Aji Nikmal Maulaawa ${ }^{1}$, Septi Andryana ${ }^{2}$, Aris Gunaryati ${ }^{3}$ \\ ${ }^{1,2}$ Universitas Nasional, J1 Sawo Manila No.61, Pejaten Bar. Ps. Minggu, Jakarta 12520 \\ ${ }^{3}$ Teknik Informatika, Fakultas Teknologi Komunikasi dan Informatika, Jakarta \\ e-mail: ${ }^{1}$ ajimaulaawa@gmail.com, ${ }^{2}$ septi.andryana@ @ivitas.unas.ac.id, \\ ${ }^{3}$ Aris.gunaryati@civitas.unas.ac.id
}

\begin{abstract}
Abstrak
Covid-19 adalah jenis penyakit yang sangat cepat perambatanya dan mudah untuk menular. disebabkan oleh virus dalam kelompok SARS-CoV-2. Bisa juga disebut Virus corona (COVID-19). Rencana pencegahan perambatan Covid-19 adalah dengan menggunakan prosedur kesehatan (pakai masker, jaga jarak dan selalu dengan cuci kedua tangan). Perancangan tersebut bertujuan untuk merancang dan membangun pintu dengan alat sanitizer automatis ini diharapkan agar menekan, mengurangi perambatan dan penyebaran virus Covid19. Disinfektan atau sanitizer yang beredar saat ini masih manual, jika masih digunakan dan digunakan secara luas oleh masyarakat dapat menularkan dan menyebarkan virus Covid-19 yang berbahaya. Faktor-faktor tersebut membuat perlu kerja keras penggunaan disinfektan otomatis tersebut untuk meminimalisir kemungkinan penyebaran COVID-19, sehingga menjaga kesehatan dan kebersihan. Alat ini dibuat untuk mengubah desain kerja sistem pada sterilizer atau sanitizer, dari manual menjadi otomatis, pembersihan lebih aman. Hasil pengujian alat yang berjalan pada sensor ultrasonik Arduino mendeteksi bahwa tangan berada pada jarak tertentu, kemudian servo bergerak menarik tali lalu melepaskan isi cairan pada sanitizer, kemudian pintu akan terbuka secara otomatis. Mencegah terjadinya sentuhan dan kontak langsung pada sanitizer dan pintu, Pentingnya rancangan ini agar menekan jumlah lonjaknya kenaikan kasus virus tersebut.
\end{abstract}

Kata kunci-Covid-19, Sanitizer, Otomatis, Arduino

\begin{abstract}
Covid-19 is a type of disease that spreads very quickly and is easy to spread. caused by a virus in the SARS-CoV-2 group. Also known as the Corona Virus (COVID-19). The plan to prevent the spread of Covid-19 is to use health procedures (wear masks, keep your distance and always wash your hands). The design aims to design and build doors with automatic sanitizers, which are expected to suppress, reduce the propagation and spread of the Covid-19 virus. Disinfectants or sanitizers currently circulating are still manual, if they are still used and widely used by the public, they can transmit and spread the dangerous Covid-19 virus. These factors make it necessary to work hard on the use of automatic disinfectants to minimize the possibility of the spread of COVID-19, thus maintaining health and hygiene. This tool is made to change the work design of the system on the sterilizer or sanitizer, from manual to automatic, cleaning is safer. The test results of the tool running on the Arduino ultrasonic sensor detects that the hand is at a certain distance, then the servo moves to pull the rope and then releases the liquid content in the sanitizer, then the door will open automatically. To prevent touching and direct contact with sanitizers and doors, the importance of this design is to reduce the number of spikes in the number of cases of the virus.
\end{abstract}

Keywords - Covid-19, Sanitizer, Automatic, Arduino 


\section{PENDAHULUAN}

$\mathrm{P}$ erkembangan pada teknologi kesehatan adalah pokok sangatlah penting bagi kehidupan. salah satu alternative mencegah kesehatan yang paling sederhana adalah dengan selalu rajin mencuci tangan, untuk menjaga tubuh. Kemajuan ilmu kesehatan dan ilmu pengetahuan teknologi terus mendorong manusia agar terus aktif berusaha mengatasi sagala sesuatu masalah yang muncul pada sekitarnya. Merupakan Salah satunya teknologi mikrokontroler yang sangat berperan bagi sebagian bidang kehidupan manusia. Untuk mengikuti menyelesaikan suatu masalah, manusia cukup banyak menguras tenaga, waktu, bahkan biaya yang sangat besar, tetapi dengan menggunakan sebuah kemajuan bagi teknologi mikrokontroler hal-hal ini bisa ditekan dan di kendalikan seminimal mungkin.

Masuknya penyakit kedalam lingkaran kehidupan manusia adalah salah satu yang disebabkan oleh infection dan bakteri ini adalah sebagai bentuk dari cara hidup yang tidak bersih. Dimana tempat yang sering terjadi berkumpulan dan berkerumunan, merupakan tempat yang withering rentan dalam penyebaran infection atau bakteri Coronavirus. Salah satu untuk menghidari penyebaran penyakit maka harus ada penerapan sistem Pintu dengan sanitizer, bagian telapak Tangan merupakan bagian pada manusia seringkali banyak digunakan untuk beriteraksi dengan manusia lainnya, seperti bersalaman, compositions memberi atau menerima sesuatu, serta interaksi yang lainnya. Adanya musibah penyebaran infection crown, membuat semua manusia di dunia menjadi tahu betapa pentingnya membersihkan tangan.

Ada banyak cara untuk menghilangkan bakteri dan bakteri, salah satunya merupakan pada pencucian dan pembersihan tangan memakai sabun dan air, dan mencuci tangan dengan hand sanitizer. Pada dasarnya ada dua jenis pembersih tangan, yaitu pembersih tangan berbasis alkohol (ABHS) dan pembersih tangan berbasis non-alkohol (NABHS). Peneliti mempelajari efektivitas hand sanitizer terhadap virus dan bakteri pernah diuji dalam sejumlah penelitian, antara lain awal pemakaian hand sanitizer yang dioperasikan bagi Kerajaan Saudi Arabia pada bakteri patogen [1]. Pembersih tangan dapat mengurangi warna kuning keemasan Tidak ada perbedaan yang signifikan jumlah koloni stafilokokus, dan pembersih tangan dengan alkohol sebagai komponen utama dan tidak dengan alkohol sebagai komponen utama tidak memiliki perbedaan yang signifikan dalam mengurangi jumlah koloni E. coli [2 ].

Pada penelitian perancangan sistem rancang bangun pembersih tangan otomatis, meliputi pembuatan pembersih tangan automatis yang bekerja menyesuaikan dengan wadah [3], menggunakan mikrokontroler pada penghitungan suatu posisi tertentu bagi sensor dan telapak tangan diposisikan kearah mata sensor lalu meletakanya dan memakai kemampuan waktu dibawahnya [4], Penggunaan ATmega328P untuk membuat pembersih tangan pintar [5], membuat pembersih tangan dan pengering otomatis [6].

Ruang desinfeksi otomatis ini dirancang untuk menekan dan perambatan menyebarnya virus COVID-19 pada daerah keramaian dan pada tempat umum atau di antara orang-orang. Ruang sterilisasi dapat digunakan di pintu masuk sekolah, toko, kantor dan tempat umum lainnya. Instal bentuk nyata dari ruang sterilisasi. Teliti proses pembersih tangan otomatis tanpa menyentuh untuk membuatnya sangat bersih. [7]

Sistem sterilisasi ruang otomatis sepenuhnya sederhana dalam jenis dan harga rendah, menggunakan bahan baja dan plastik tebal sebagai lapisan rongga. spray pompa nozzle 12 volt berjumlah 15 titik, sensor bergerak, sensor gerak memakai basis switch bagi rangkaian mosfet pada bahan-bahan disinfektan percampuran tersebut di dalam jerigen. [8] Disinfektan menggunakan detol antiseptik agar lebih aman terhadap tubuh manusia dan mampu kerja alat ini yaitu pompa spray akan menghisap cairan antiseptic pada jerigen yang sudah di campur dengan campuran tertentu, yang nantinya akan menyemprotkan dengan automatis sewaktu pada orang yang sedang memasuki area bilik sterilizer chamber, lalu sensor gerak akan membaca

Aji , et.,al [Rancang Bangun Sistem Pintu Antisipasi Covid-19 Dengan Sanitizer Otomatis Menggunakan Sensor Ultrasonik Arduino 
pergerakan manusia di dalam bilik yang diletakan diatas chamber. Setelah orang tersebut keluar dari bilik sterilizer chamber, sensor gerak akan membaca dan penyemprotan otomatis akan berhenti bekerja. [9]

Sanitizer dapat membunuh kuman, bakteri dan virus pada sebab ini penulis merangkai penelitian dengan judul "Rancang Bangun Hand Sanitizer Otomatis Menggunakan Sensor Ultrasonik Berbasis Atmega 328". Tujuan pada dirancanganya perangkat ini agar bisa menurunkan penyebaran Covid-19 dan mampu membantu agar dapat efektif waktu dipergunakan untuk seluruh masyarakat. [10]

\section{METODE PENELITIAN}

Untuk metode penelitian ini memakai metode rancang bangun, rancang bangun ini dimulai dari studi literlatur dan menganalisa kebutuhan system dan di akhiri dengan hasil simulasi atau hasil uji coba.

\subsection{Tahapan Penelitian}

Pada tahapan penelitian dalam pembuatan rancang bangun pintu antisipasi covid-19 dengan sanitizer otomatis meliputi:

a) Analisa Kebutuhan

Penganalisan ini dijalankan agar bisa melihat jumlah kebutuhan rangkaian komponen yang akan dipakai. Saat mekanisme pembuatan system rangkaian. Meliputi perancangan mekanik, hardware, software, sehingga mekanisme rancangan sistem sepenuhnya. Analisa juga mendokumentasikan progress sistem informasi menetapkan semua proses mulai dari input, pemprosesan, output, penyimpanan dan pengontrolan. Analisa dibutuhkan rancangan pada posisi awalan studi awal yang berfungsi bagi pengkelompokan permasalahan pada kebutuhan spesifikasi rancangan.

b) Perancangan Pada Hardware

Input dari mikrokontroler Arduino Uno yaitu sensor Ultrasonic. Sedangkan output adalah motor servo. Proses Sensor Ultrasonic mendeteksi adanya tangan yang mendekat. Sehingga akan membuat motor servo bergerak dan mengeluarkan antiseptik hand sanitizer. Fungsi Motor servo untuk penggerak, disaat motor servo berfungsi untuk mendorong keluarnya cairan sanitizer.

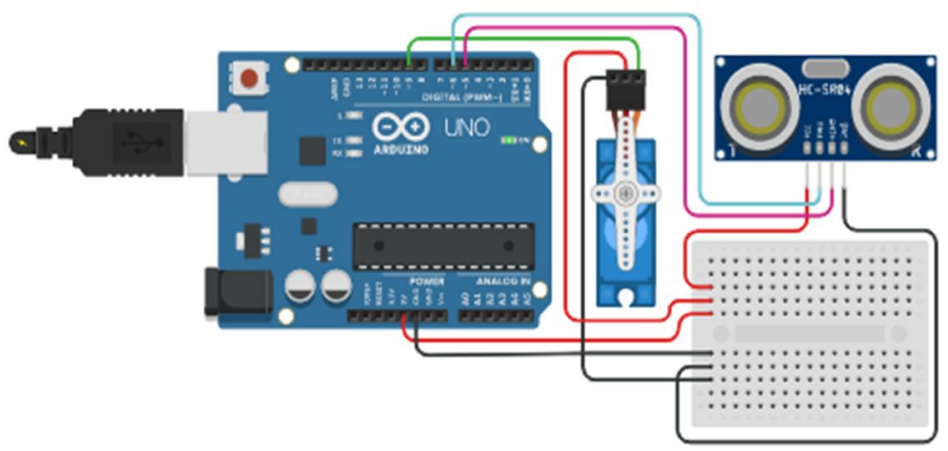

Gambar 1. Perancangan Rangkaian Hardware

Aji , et.,al [Rancang Bangun Sistem Pintu Antisipasi Covid-19 Dengan Sanitizer Otomatis Menggunakan Sensor Ultrasonik Arduino 
c) Perancangan Pada Software

Perancangan pada software yaitu terkait pemrograman terkait dengan bagaimana sanitizer otomatis ini mampu menjalankan sesuai dengan rencana. Pada saat sistem bekerja dan sedang berjalan, sensor berjalan memastikan agar pendeteksian pada objek yang mendekati ultrasonic sensor, sebuah tangan dengan jangkauan jarak tertentu. Ketika terdapat objek sedang mendekat yang terdeteksi maka sensor Ultrasonik dapat mengirimkan sebuah sinyal pada Arduino Uno lalu menyalakan motor servo. Dan pada Sebaliknya, jika tidak ada yang mendekat, maka mendeteksi adanya sebuah objek pada sensor, sistem akan bersiap.

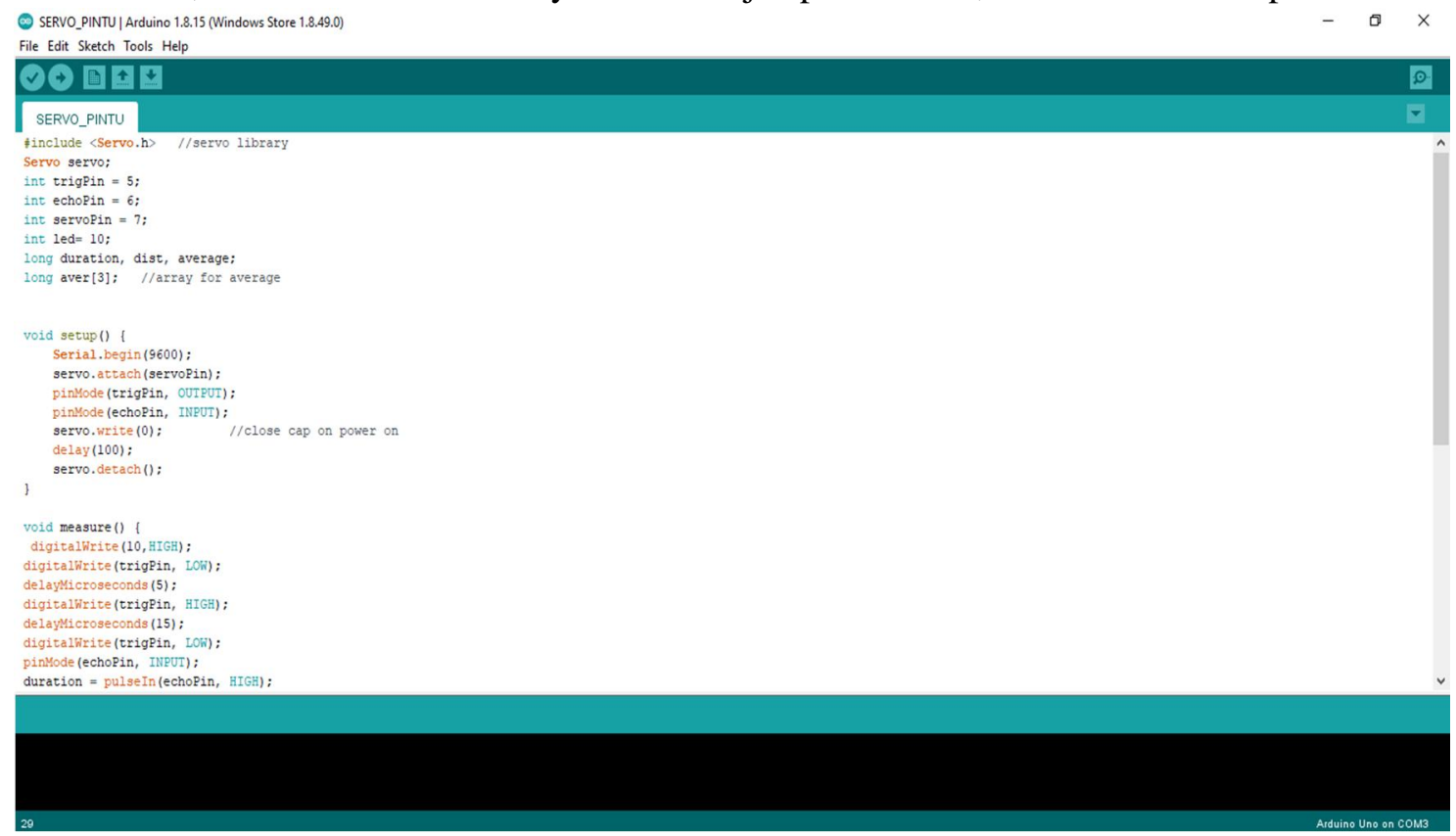

Gambar 2. Perancangan Program pada Software Arduino IDE

d) Perancangan Mekanik

Perancangan Perancangan mekanik yaitu meliputi bentuk rangkian desain perancangan mekanik pada alat sanitizer otomatis. Dengan perancangan rangkaian alat yang beberapa komponenya membutuhan perangkat hardware yang sesuaikan dengan penempatan sanitizer yang akan diterapkan sesuai fungsinya Gambar 3 menujukkan desain perancangan mekanik pada sanitizer otomatis yang akan digunakan.
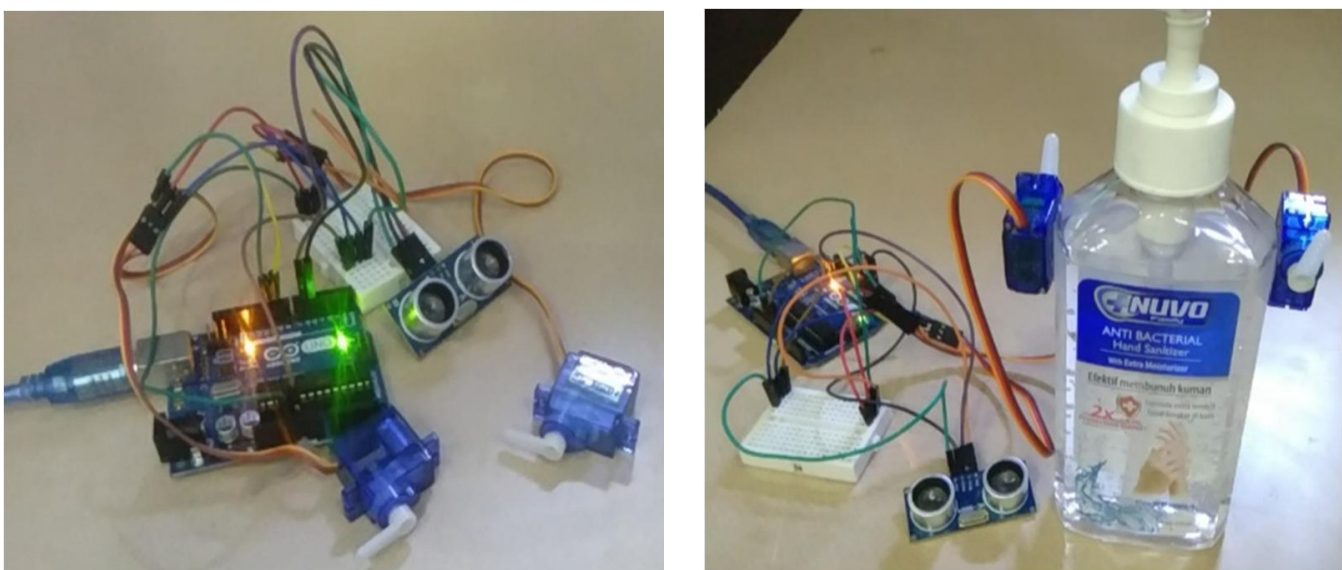

\section{Gambar 3. Perancangan Mekanik}

Aji , et.,al [Rancang Bangun Sistem Pintu Antisipasi Covid-19 Dengan Sanitizer Otomatis Menggunakan Sensor Ultrasonik Arduino 


\section{2 Peralatan dan bahan-bahan}

Bahan dan material ini berupa hardware dan software. berjalannya perancangan tersebut memakai beberapa bahan dan peralatan. Diperlukan peralatan dengan bahan yang dipergunakan untuk merancang sanitizer otomatis dapat dilihat seperti pada Tabel 1

Tabel 1. Peralatan dan Bahan-bahan

\begin{tabular}{|c|l|l|c|}
\hline No & \multicolumn{1}{|c|}{ Alat } & \multicolumn{1}{|c|}{ Deskripsi } & Jumlah \\
\hline 1 & Arduino Uno R3 & Berperan untuk pengendali/pengontrol & 2 \\
\hline 2 & Sensor Ultrasonik & Berperan untuk pendeteksi objek & 2 \\
\hline 3 & Motor Servo & Berperan untuk penggerak sanitizer & 3 \\
\hline 4 & Kabel Jumper & Berperan untuk media penghubung & 40 \\
\hline 5 & Breadboard & Berperan untuk perangkai & 2 \\
\hline
\end{tabular}

\section{3 Diagram Perancangan Sistem}

Diagram perancangan pintu antisipasi covid-19 dengan sanitizer otomatis adalah sesuatu perancangan yang diciptakan agar mengurangi banyaknya sentuhan dan berkontakan langsung pada sebuah tutup/wadah sanitizer saat sedang dipakai, pada kebanyakan orang. Sanitizer otomatis ini memakai mikrokontroler Arduino Uno untuk menjalankan pengendalian yang direncanakan, sensor ultrasonik mejadi input pada sistem rancangan dan servo sebagai output dari sistem ini.

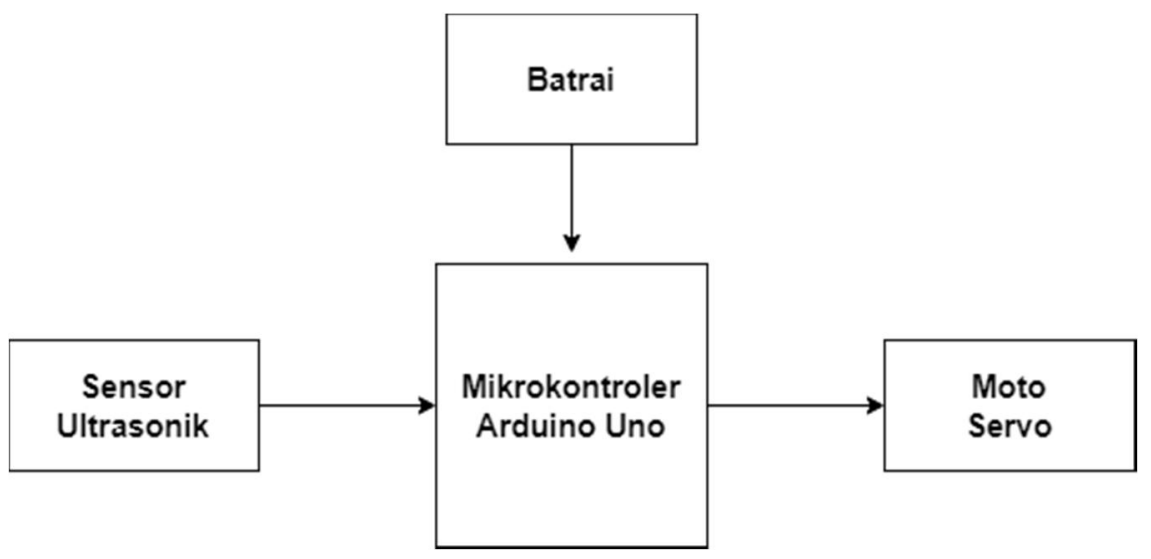

Gambar 4. Diagram Rancangan Sistem

\section{HASIL DAN PEMBAHASAN}

\section{1 Flowchart}

Flowchart pintu antisipasi covid-19 dengan sanitizer otomatis adalah deskripsi atau sebuah penggambaran alur program secara detail dengan menngunakan simbol sebagai penggambaran metode dengan menghubungkan metode lainnya. untuk mengawali tahapan sebuah penelitian maka diperlukan sebuah rancangan sistem serta menentukan komponen yang 
di perlukan untuk merancang prototype perangkat keras. pada gambar dibawah merupakan sebuah alur program I/O pada Rancang bangun sistem pintu dengan sanitizer otomatis

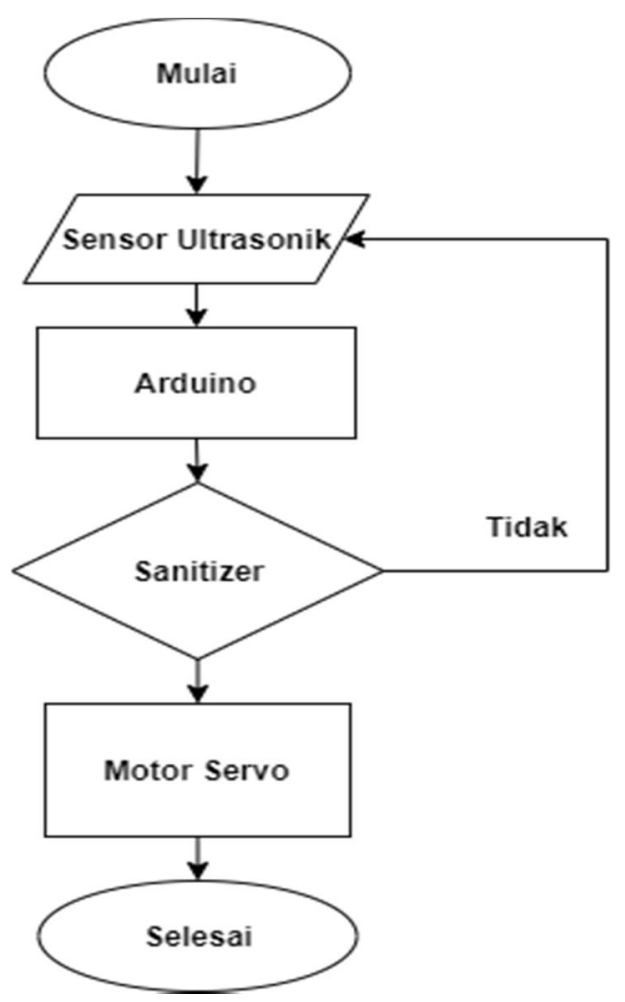

Gambar 5. Flowcart

Rancangan Flowcart pintu antisipasi covid-19 dengan sanitizer otomatis yaitu ultrasonik sensor untuk pendeteksi yang membaca adanya objek tangan pada posisi tertentu lalu alat rancangan Arduino Uno untuk mengatur dan mengendalikan pada sistem sanitizer otomatis ini, output pada rancangan ini merupakan motor servo yang akan menarik tambang agar menekan sanitizer.

\subsection{Implementasi dan Hasil}

Pada Langkah ini adalah keseluruhan rancangan implementasi system yang akan digabungkan dengan satu perancangan sistem sehingga pintu dan sanitizer dapat berjalan sesuai yang dirancang, Hasil pada rancangan mekanik pembuatan pintu antisipasi covid-19 dengan sanitizer otomatis, yaitu membuat pergabungan pada sistem dapat berfungsi baik dan dapat digunakan sesuai dengan yang direncanakan. bisa dilihat pada Gambar 6 

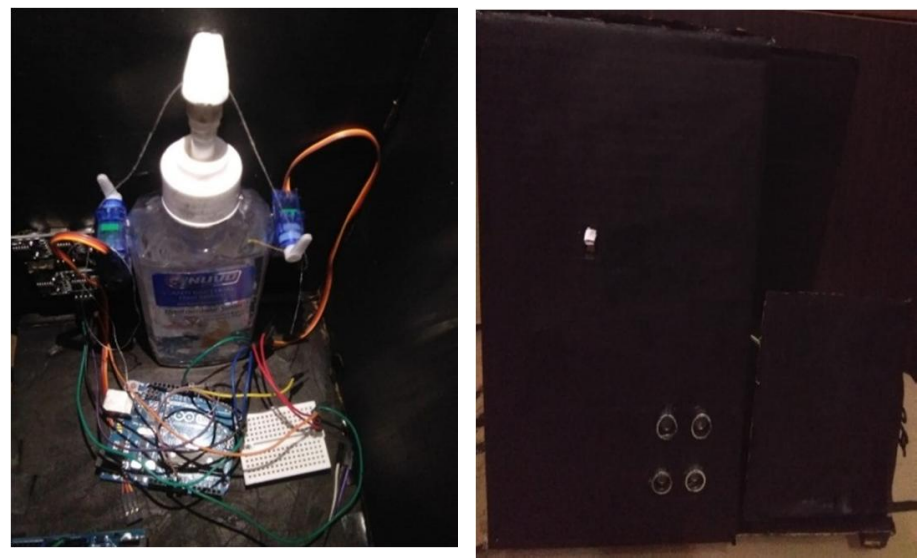

Gambar 6. Hasil Perancangan Mekanik

Hasil Pintu antisipasi covid-19 menggunakan sanitizer otomatis merupakan sensor ultrasonik mejadi deteksi objek yang akan membaca tangan dalam jeda eksklusif menjadi input, dan akan diteruskan menuju mikrokontroler Arduino Uno menjadi indera pemroses dan mengendalian motor servo yang berfungsi menjadi hasil buat menarik tali supaya penekan tutup sanitizer dan mengeluarkan cairan sanitizer, Lalu pintu Automatis Terbuka. sehingga kita dapat mencuci tangan tanpa menyentuh sanitizer dan menyentuh pintu.

Tabel 2. Pengujian dan hasil

\begin{tabular}{|c|l|l|l|l|}
\hline No & Jarak & Reaksi Servo & \multicolumn{1}{|c|}{ Reaksi Sanitizer } & \multicolumn{1}{|c|}{$\begin{array}{l}\text { Raktu } \\
\text { Reaksi }\end{array}$} \\
\hline 1 & $4 \mathrm{~cm}$ & Bergerak & $\begin{array}{l}\text { Sanitizer Menyemprot } \\
\text { dan pintu terbuka }\end{array}$ & 1 Detik \\
\hline 2 & $7 \mathrm{~cm}$ & Bergerak & $\begin{array}{l}\text { Sanitizer Menyemprot } \\
\text { dan pintu terbuka }\end{array}$ & 1 Detik \\
\hline 3 & $11 \mathrm{~cm}$ & Bergerak & $\begin{array}{l}\text { Sanitizer Menyemprot } \\
\text { dan pintu terbuka }\end{array}$ & 1 Detik \\
\hline 4 & $13 \mathrm{~cm}$ & Tidak Bergerak & $\begin{array}{l}\text { Tidak Meyemprotkan } \\
\text { Sanitizer dan pintu tidak } \\
\text { terbuka }\end{array}$ & \\
\hline
\end{tabular}

Berdasarkan Tabel 2 hasil penguji percobaan rancangan system ini mendapatkan hasil, posisi sensor membaca dari 0-10 $\mathrm{cm}$. mendapatkan Kelangsungan reaksi pada servo meter sebesar 1 detik. Pada jarak $13 \mathrm{~cm}$ servo tidak bergerak karna objek pada jarak tersebut terlalu jauh.

\section{KESIMPULAN}

Berdasarkan hasil pengujian bahwa sanitizer dapat tersemprot dan pintu terbuka pada jarak kurang dari $13 \mathrm{~cm}$, dan sebaliknya jika jarak objek melebihi jarak tersebut makan cairan tidak tersemprot dan pintu tidak terbuka, Pembuatan Rancang bangun sistem pintu dengan sanitizer otomatis ini adalah suatu bentuk rancangan dan upaya pencegah perambatan penularan virus corona menggunakan sanitizer otomatis. Dengan dibuatnya pengontrolan pintu dengan

Aji , et.,al [Rancang Bangun Sistem Pintu Antisipasi Covid-19 Dengan Sanitizer Otomatis Menggunakan Sensor 
sanitizer ini adalah salah satu upaya pencegahan penularan Coronavirus dengan harapan mengurangi kemungkinan terjadinya penularan Coronavirus akan lebih mudah saat dipergunakan oleh banyak orang.

\section{SARAN}

Saran bagi penelitian selanjutnya adalah agar dapat lebih memperbaiki lagi dan meningkatkan pengembangan pada system dan alat ini, dapat lebih memperluas kreatifitas dan inovasikan desain rancangan agar lebih baik lagi saat di oprasikan. Dan bisa mempembaharui alat atau perangkat dengan mikrokontroler yang mempuni dan kekinian lalu menembahkan beberapa komponen agar dapat di gabungkan dan di variasikan untuk meningkatkan fitur-fitur pada system.

\section{DAFTAR PUSTAKA}

[1] A. Ghahary, A. Golin, and D. Choi, 2020, "Hand Sanitizers: A Review of Ingredients, Mechanisms of Action, Modes of Delivery, and Efficacy Against Coronaviruses,” Am. J. Infect. Control, Vol. 48, Jun. doi: 10.1016/j.ajic.2020.06.182.

[2] R. Djalante et al., 2020, "Review and Analysis of Current Responses to COVID- 19 in Indonesia: Period of January to March 2020,” Prog. Disaster Sci., Vol. 6, p. 100091, Apr. doi: 10.1016/j.pdisas.2020.100091.

[3] N. Singh and S. Garima, 2020, "Fatality in COVID 19: an Overview of Causes of Death and Organ Involvement,” Int. J. Adv. Med., Vol. 7, p. 1190, Jun. doi: 10.18203/23493933.ijam20202598.

[4] W Rohmah, N. H. 2017. "Augmented Reality-Based Application as Instructional Media on The Material of The Input and Output Device Component". Indonesian Journal of Informatics Education.

[5] J. Lee, J.-Y. Lee, S.-M. Cho, K.-C. Yoon, Y. J. Kim, and K. G. Kim, 2020, “Design of Automatic Hand Sanitizer System Compatible with Various Containers," Healthc. Inform. Res., Vol. 26, No. 3, pp. 243-247, Juldoi: 10.4258/hir.2020.26.3.243.

[6] S. Bondurant, T. McKinney, L. Bondurant, and L. Fitzpatrick, "Evaluation of A Benzalkonium Chloride Hand Sanitizer In Reducing Transient Staphylococcus Aureus Bacterial Skin Contamination In Health Care Workers,” Am. J. Infect. Control, Vol. 48, no. 5, pp. 522-526, May 2020, doi: 10.1016/j.ajic.2019.08.030.

[7] A. S, “Review on Automatic Sanitizer Dispensing Machine,” Int. J. Eng. Res., Vol. V9, Jul. 2020, doi: 10.17577/IJERTV9IS070307.

[8] M. A. S. Antara, I. W. A Suteja, \& A Prabowo. 2020:” Sterilizer Chamber Sebagai Satu Alat Pencegahan Penyebaran Virus Covid-19” Vol. 2 No. 2, Jurnal LeECOM.

Aji , et.,al [Rancang Bangun Sistem Pintu Antisipasi Covid-19 Dengan Sanitizer Otomatis Menggunakan Sensor Ultrasonik Arduino 
[9] R. Muzawi, Y. Efendi, \& U. Rio, 2020. "Prototype Alat Physical Distancing Covid-19 Mengunakan Arduino Uno" JOISIE (Journal of Information Systems and Informatics Engineering), [S.1.], v. 4, n. 2, p. 121-127, dec. ISSN 2527-3116.

[10] H. Hendri, 2019 "Pembersih Tangan Otomatis Dilengkapi Air, Sabun, Handdryer dan Lcd Menggunakan Sensor Infrared Berbasis Arduino,” Teknologi, Vol. 8, No. 1, Art. No. 1, Feb. 